\title{
Determination of Agronomic Characteristics as Selection Criteria in Potato Crossing Lines
}

\author{
DOI: 10.18196/pt.v10i1.7571
}

\author{
Erny Ishartati $^{{ }^{*}}$, Sufianto ${ }^{1}$, Aulia Zakia ${ }^{1}$, Made Jane Mejaya $^{2}$, Rudy Madianto ${ }^{3}$ \\ ${ }^{1}$ Department of Agrotechnology, Universitas Muhammadiyah Malang, Jl. Raya Tlogomas No. 246, Malang, 65144, East Java, Indonesia \\ ${ }^{2}$ Indonesian Center and Development for Food Crops Research and Development, Jl. Raya Kendalpayak km 8, PO Box 66 Malang 65101, East \\ Java, Indonesia \\ ${ }^{3}$ Sumber Brantas, Bumiaji, Batu, 65338, East Java, Indonesia \\ *Corresponding author, email: ishartati.erny@gmail.com
}

\begin{abstract}
Vegetative propagation of potato decreases variation in commercially cultivated varieties. Induction of variability in potatoes is needed for crop improvement. Selection is selecting the best individual plants based on the desired characteristics, which will be effective when suitable characteristics are used. The objective of this study was to determine the agronomic characteristics for the selection of potato crossing lines through heritability, genetic variability,

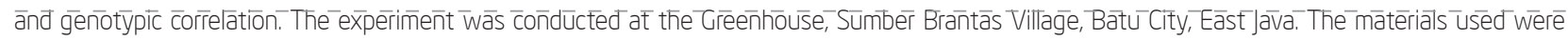
30 potato lines resulting from LJPRSD1 x AP-4. This study was arranged in a complete randomized design (RCD) with three replications. The agronomic characteristics observed include plant height, stem diameter, number of leaves, the diameter of tuber, number of tubers, tuber length, weight per tuber, starch, and glucose. Almost all characteristics observed showed high heritability values, except stem diameter and tuber length. The genetic variability in stem diameter, tuber diameter, and tuber length was low, whereas the genetic variability in other characteristics was slightly low. The genotypic correlation was significant between characteristics, except between starch content and weight per tuber. Meanwhile, the agronomic characteristics used for selection are plant height, diameter of tuber, number of tubers.
\end{abstract}

Keywords: Agronomic characteristics, Genetic variability, Genotypic correlation, Heritability

\section{ABSTRAK}

Perbanyakan kentang secara vegetatif menyebabkan variasi varietas kentang komersial kurang berkembang. Induksi variabilitas pada kentang sangat dibutuhkan untuk perbaikan tanaman. Seleksi adalah kegiatan memilih individu terbaik berdasarkan sifat tanaman yang diinginkan. lika karakter seleksi yang digunakan tepat, kegiatan seleksi menjadi sangat efektif. Tujuan dari penelitian ini adalah menentukan karakter agronomis yang tepat, dan digunakan dalam pemilihan karakter populasi galur kentang silang melalui heritabilitas, keragaman genetik, serta korelasi genotip. Percobaan dilakukan di Rumah Kaca, Desa Sumber Brantas, Kota Batu, Jawa Timur. Bahan yang digunakan adalah 30 galur kentang sebagai hasil persilangan varietas LJPRSD 1 x AP-4. Rancangan percobaan yang digunakan adalah Rancangan Kelompok Lengkap Teracak (RKLT) dengan 3 ulangan. Karakter agronomi yang diamati adalah tinggi tanaman, diameter batang, jumlah daun, diameter umbi, jumlah umbi, panjang umbi, berat per umbi, kadar pati, dan glukosa. Hasil heritabilitas pada hampir semua karakter memiliki nilai tinggi, kecuali untuk diameter batang dan panjang umbi. Keragaman genetik pada diameter batang, diameter umbi, panjang umbi rendah, sedangkan karakter lain agak-rendah. Korelasi genotip signifikan antara karakter, kecuali kadar pati dan bobot per umbi. Karakter agronomi yang dapat digunakan untuk seleksi adalah tinggi tanaman, diameter umbi, dan jumlah umbi.

Kata kunci: Heritabilitas, Karakter agronomi, Keragaman genetik, Korelasi genotip

\section{INTRODUCTION}

Potato (Solanum tuberosum) is an economi- productivity, the role of breeding programs is imcally important crop in Indonesia, as shown by portant, which highly depends on the availability its increasing yearly demand (Statistik Konsumsi of genetic variability.

Pangan, 2018). The consumption of potatoes is The genetic variability of potato germplasm rising, especially in the big cities where people is an important aspect of success in the breeding prefer fast food to traditional rice. Therefore, the program. Hybridization among parents with broad production of potatoes should be increased by genetic variability may increase the genetic variincreasing plant productivity. To increase plant ability of the desired characteristics. The plant's 
characteristic variability that will be derived is the main requirement in breeding. The commercial potato varieties do not yet have many variations, due to the vegetative propagation of plants. Therefore, the induction of variability becomes one of the potato plant improvement programs (Mondal et al., 2007). Observation of qualitative and quantitative characterizations determines the next step in the breeding program.

The plant improvement program begins from observing qualitative and quantitative characteristics to determine the next step in the breeding program. The quantitative characteristics that play an important role include tuber yield and primary yield components (number of tubers per plant, tuber weight per plant, and tuber size). Tuber yield is an important characteristic as it measures the economic productivity of potatoes. Estimates of heritability and genetic advance among important characteristics could provide a basis information for efficient potato breeding programs and information on the performance of parents in hybrids (Mondal et al., 2007).

The genetic variability of 31 potato genotypes grown in Bangladesh indicated that plant height, the number of leaflets/compound leaf, leaf area, leaf coverage/plant, and fresh weight/compound exhibited high genetic advance and heritability. Therefore, these characteristics might be advocated to improve the yield by effective selection. Breeding is conditioned by the interrelationship of genotypic and environmental variation in different characteristics. In that case, the variability is divided into its heritable and non-heritable components with the help of suitable genetic parameters. Genotypic coefficient of variation (GCV), heritability estimates, and genetic advance are the genetic parameters. It is also beneficial to make a comparison for few characteristics that desirable ones in different strains
(Nasiruddin et al., 2017). A similar study was also conducted to estimate the genetic variability and advance between the genotypes. The considerable variations among the genotypes studied were indicated by all genotypes varied significantly (Rahman et al., 2016).

Based on the combined analysis of variance performed over 2013 to 2014, were related Broad-sense heritability values of some quantitative characteristics in a potato population comprising 21 genotypes grown at Bornova, Izmir, Turkey, show that plant height, the number of tubers, the weight of single tuber, yield, and starch content had a moderate to high-level heritability values (Ozturk and Yildirim, 2014). So that the genotypic characteristic can be used as a guide in potato selection.

Highly heritability and correlation of potato genotypes were shown in fresh shoot weight, fresh root weight, root length, root diameter, number of root-knot, number of tubers, and tubers weight. All variables showed significant correlation so that it could be potentially used for characteristic selection, especially resistance varieties for nematode (Lubis et al., 2018). Such parameters with high heritability assessment can be used as selection criteria for plant breeding programs.

The information of gene action, genetic variability, and heritability is a useful tool for the selection in the crop improvement program and for designing efficient selection strategies in plant breeding. Many characteristics of potatoes are inherited in a quantitative manner. Selection is selecting the best individual plants based on the desired characteristics (Phillips and Wolfe, 2005). Selection will be effective if the right characteristic is used. The selection of the desired characteristic is based on its genetic values, such as heritability or correlation coefficient value (Nasution, 2010). Selection can be performed using one or several 
characteristics (Babu, 2012; Rachman, 2010).

This study aimed to determine agronomic characteristics that can be used as selection criteria in potato populations by estimating heritability, genetic variability, genotypic correlation, and selection of lines.

\section{MATERIALS AND METHODS}

The experiment was conducted at the Greenhouse, Sumber Brantas Village, Batu City, East Java. The treatment consisted of 30 lines of potatoes resulting from the crossing of LJPRSD1 $\mathrm{x}$ var AP-4 var [Lejifer Solanum Denisum x Ariza] x AP-4.]. The experiment was laid out in complete randomized design (RCD) with three replications. The research was started by sown the seeds in a nursery tub placed in the greenhouse using planting media of soil and cocopeat $(1: 1 \mathrm{v} / \mathrm{v})$. Then, 30 lines/genotypes of potato seeds were planted in the polybag (24 seeds each line and one seed per polybag per hole), and the spacing used was $40 \times 40$ $\mathrm{cm}$. The agronomic characteristics observed were plant height $(\mathrm{cm})$, stem diameter $(\mathrm{cm})$, number of leaves, the diameter of tuber $(\mathrm{cm})$, number of tubers, length of tuber $(\mathrm{cm})$, weight per tuber $(\mathrm{g})$, levels of starch (\%), and glucose (\%).

The expectation of the square of each parameter, genotypic coefficient of variation (GCV), and phenotypic coefficient of variation (PCV) was calculated based on the formula by Singh \& Chaudhary (1979). Genotypic variations were tested by analysis of variance at a $5 \%$ significance level based on Akmal et al., (2014).

The data obtained were analyzed of variance (Steel et al., 1997). The genotypic and phenotypic correlations were calculated by Kwon and Torrie (1964) technique. Estimation analysis of the value of genetic parameters used is as follow: a). The estimation of broad sense heritability is based on the ratio of total genetic variance to total phenotypic variance (Zen, 2012). The following equation assumes the value of broad sense heritability.

$$
h_{b s}^{2}=\frac{\delta_{G}^{2}}{\delta_{P}^{2}}
$$

According to Stansfild (1991) and Khan et al., (2007), the values of heritability are divided into three categories: high $\left(h^{2}>0.5\right)$, moderate $\left(0.2<h^{2}\right.$ $\leq 0.5)$, and low $\left(h^{2} \leq 0.2\right)$.

b). Genotypic coefficient of variation (GCV) and phenotypic coefficient of variation (PCV) were calculated based on Singh \& Chaudhary (1979) equation.

$$
\begin{aligned}
& K K_{G}=\frac{\sqrt{\sigma_{g}^{2}}}{X} \times 100 \% \\
& K K_{P}=\frac{\sqrt{\sigma_{p}^{2}}}{X} \times 100 \%
\end{aligned}
$$

$\mathrm{KK}_{\mathrm{G}}=$ Genotypic coefficient of variation

$\mathrm{KK}_{\mathrm{p}}=$ Phenotypic coefficient of variation

$\sigma_{g}^{2}=$ Genotypic variance

$\sigma_{p}^{2}=$ Phenotypic variance

$\mathrm{X}=$ Rate

According to the following equation, the genotypic variance was determined based on genotypic variance and standard deviation of genotypic variance.

$$
\left.\sigma_{G}^{2}=\sqrt{\frac{2}{r^{2}}} \frac{K T_{G}{ }^{2}}{\left[b_{G}+2\right.}+\frac{K T_{E^{2}}}{d b_{E}+2}\right]
$$

$\sigma_{g}^{2}=$ Genotypic variance

$\mathrm{KTG}=$ Mean square of error

$\mathrm{KTE}=$ Mean square of environment

$\mathrm{r} \quad=$ number of replications

$\mathrm{dbG}=$ degrees of freedom for error

$\mathrm{dbE}=$ degrees of freedom for environment 
If $\alpha_{G}^{2}>2^{\alpha_{G}^{2}}$ : Broad genotypic variance, whereas $\alpha_{G}^{2}<2^{\alpha_{G}^{2}}$ : narrow genotypic variance (Pinaria et al., 1995).

c) Genotypic correlation coefficient was determined based on Singh and Chaudhary (1979) equation, then tested using $\mathrm{Z}$ test at the level of 5\%. Correlation analysis is used to predict the closeness between agronomic characters, using the following equation.

$$
\hat{r}_{x y}=\frac{\operatorname{Cov}_{x y}}{\sqrt{\delta_{x}^{2} \delta_{y}^{2}}}
$$

$\hat{\mathrm{r}}_{\mathrm{xy}} \quad=$ correlation between $\mathrm{x}$ and $\mathrm{y}$ characteristics

$\mathrm{Cov}_{\mathrm{xy}}=$ variability between $\mathrm{x}$ and $\mathrm{y}$ character istics

$\sigma_{\mathrm{x}}^{2} \quad=$ population variance for $\mathrm{x}$ characteristics

$\sigma_{\mathrm{y}}^{2} \quad=$ population variance for $\mathrm{y}$ characteristics

d) To find out the direct and indirect effects of each characteristic on the yield, path analysis was used, as proposed by Singh and Chaudhary (1979) as follow:

$$
\mathrm{R}_{\mathrm{xy}}=\mathrm{R}_{\mathrm{xx}} \mathrm{xP}_{\mathrm{xy}} \longrightarrow \mathrm{P}_{\mathrm{xy}}=\mathrm{R}_{\mathrm{xy}} \mathrm{x} \mathrm{R}-1_{\mathrm{xx}}
$$

$\mathrm{R}_{\mathrm{xy}}=$ dependent and independent characteristic correlation values

$\mathrm{R}-1_{\mathrm{xx}}=$ matrix inverse between dependent characteristics

$\mathrm{P}_{\mathrm{xy}}=$ cross correlation coefficient (direct effect)

\section{RESULTS AND DISCUSSION}

Determination of Genetic Variations

The standard deviation value of the agronomic characteristics of 30 lines of potato resulting from crossing is high, and the population range values are broad (Table 1). The analysis of variance showed that the genotypes of the lines resulting from crossing have a very significant difference in the plant height, stem diameter, number of leaves, the diameter of tuber, number of tubers, length of tubers, weight per tuber, starch content, and glucose (P-value <,0001). The significant values of the variable analysis indicate the variation between the lines for all characteristics tested so that selection can be made. According to Hartati et al., (2002) and Herawati et al., (2009), populations that can be selected are those that have high variability. Analysis of variance showed significant variation between the lines for all characteristics tested. Therefore, selection can be made.

Standard deviation and population range values are used to see the spread of values on agronomic characteristics. A high standard deviation and broad range values indicate that a character has diffuse data so that it has high variability (Singh and Chaudhary, 1979). Variability found in agronomic characteristics can also be predicted through the coefficient of variation and analysis of variance (Akhmadi et al., 2017).

The coefficient of variation for each agronomic characteristic is below $30 \%$. The coefficient of variation shows the heterogeneity of plants in the population (Zen, 2012). According to Bowman (2001), the lower the coefficient of variation found in the data, the higher the degree of accuracy. This shows the conclusions generated in this study have high validity.

Estimation of genetic parameters in the selection process is very important because the implementation of visual selection by selecting a good phenotype does not produce satisfactory results without being guided by the values of estimating genetic parameters carried out in the selection process. Variability as a genetic parameter in the selection process is one of the first steps in assembling new varieties. Plants with narrow genetic variability are not good enough to be used as parents in developing varieties. In contrast, plants with 
Table 1. Average and population range values of agronomic characteristics of 30 potato lines resulted from crossing

\begin{tabular}{lccc}
\hline Characteristics & Mean Square & Average \pm SD & Population Range \\
\hline Plant height $(\mathrm{cm})$ & $548.23^{* *}$ & $37.97 \pm 13.62$ & $24.35-61.60$ \\
Stem diameter $(\mathrm{cm})$ & $0.48^{* *}$ & $0.92 \pm 0.24$ & $0.68-1.16$ \\
Number of leaves & $1474.07^{* *}$ & $76.40 \pm 33.13$ & $43.27-109.53$ \\
Diameter of tuber $(\mathrm{cm})$ & $0.48^{* *}$ & $2.56 \pm 0.40$ & $2.16-2.96$ \\
Number of tubers & $47.33^{* *}$ & $11.24 \pm 4.06$ & $7.18-15.3$ \\
Length of tubers $(\mathrm{cm})$ & $4.20^{* *}$ & $6.44 \pm 1.35$ & $5.09-7.79$ \\
Weight per-tuber $(\mathrm{g})$ & $476.19^{* *}$ & $29.40 \pm 12.61$ & $16.79-42.01$ \\
Starch content $(\%)$ & $1.49^{* *}$ & $6.07 \pm 1.35$ & $4.72-7.42$ \\
Glucose $(\%)$ & $7.47^{* *}$ & $1.94 \pm 0.65$ & $1.29-2.56$ \\
\hline
\end{tabular}

Remarks: ** significant $(\mathrm{P}<0.0001)$

Table 2. Genotypic variance, phenotypic variance, broad sense heritability, and genotypic phenotypic coefficient of variation values on several agronomic characteristics of 30 potato lines resulted from crossing

\begin{tabular}{|c|c|c|c|c|c|c|c|c|}
\hline \multirow{2}{*}{ Characteristics } & \multirow{2}{*}{$\delta^{2} \mathrm{~g}$} & \multirow{2}{*}{$\delta^{2} \mathrm{p}$} & \multicolumn{2}{|c|}{ Heritability } & \multicolumn{2}{|c|}{$\begin{array}{c}\text { Genotypic coefficient of } \\
\text { variation (GCV)\% }\end{array}$} & \multicolumn{2}{|c|}{$\begin{array}{c}\text { Phenotypic coefficients of } \\
\text { variation (PCV)\% }\end{array}$} \\
\hline & & & Value & Category & Value & Category & Value & Category \\
\hline Plant height & 182.36 & 183.50 & 0.99 & High & 0.35 & High & 0.36 & High \\
\hline Stem diameter & 0.12 & 0.24 & 0.49 & Moderate & 0.13 & High & 0.19 & High \\
\hline Number of leaves & 485.17 & 503.74 & 0.96 & High & 0.33 & High & 0.34 & High \\
\hline Diameter of tuber & 0.15 & 0.18 & 0.83 & High & 0.15 & High & 0.17 & High \\
\hline Number of tubers & 14.83 & 17.67 & 0.84 & High & 0.33 & High & 0.36 & High \\
\hline Length of tubers & 0.93 & 2.34 & 0.40 & Moderate & 0.14 & High & 0.23 & High \\
\hline Weight per-tuber & 158.72 & 158.75 & 1.00 & High & 0.43 & High & 0.43 & High \\
\hline Starch content & 0.49 & 0.50 & 1.00 & High & 0.37 & High & 0.38 & High \\
\hline Glucose & 2.47 & 2.53 & 0.97 & High & 0.26 & High & 0.26 & High \\
\hline
\end{tabular}

broad genetic variability are likely to be developed into new varieties as desired. High variability can also improve selection response because the selection response is directly proportional to genetic variability. However, it is challenging to learn a characteristic by looking at genetic variability only. Another genetic parameters needed to study the character of a plant is heritability. Heritability is a genetic parameter that is used to measure the ability of a genotype in a plant population to inherit its characteristic or an estimation that measures the extent to which the appearance of a genotype in a population is mainly caused by the role of genetics (Acquaah, 2007; Govindaraj et al., 2014). In general, high heritability and high genetic variability will have a high genotypic coefficient of variation (GCV).
Broad-sense Heritability and Genetic Coefficient of Variance

Heritability shows whether genetic factors or environmental factors influence phenotype. If the heritability is high, genetic factors have more role than environmental factors, whereas if the heritability is low. The estimated value of heritability indicates that genetic and environmental factors influence the phenotype.

In this study, the broad sense heritability values range in Table 2. A total of 7 characteristics have a high heritability value, including plant height, number of leaves, the diameter of tuber, number of tubers, weight per-tuber, starch content, and glucose. Meanwhile, two characteristics have moderate heritability, including stem diameter and length of tubers. Similar results were also obtained, as reported by Pangemanan et al., (2013); Ozturk and Yildirim (2014) in several potato genotypes. 
Heritability is a variable that determines whether the differences in the appearance of a characteristic are caused by genetic or environmental factors (Acquaah, 2007). High heritability value indicates that a character has large genetic variability, thereby providing opportunities for genetic improvement in plant breeding programs (Acquaah, 2007; Govindaraj et al., 2014). Selection can be performed more effectively on a characteristic with a high estimated heritability value. Agronomic genetic variability of 30 potato lines resulting from crossing is shown by a variability of genotypes and coefficients of variation, indicating broad criteria. The value of heritability ranges from high to moderate, as shown in Table 2.

Characteristics with high heritability values indicate that genotypes play a bigger role than environments' variability (Acquaah, 2007; Pratap et. al., 2012). If genotypes play a bigger role, the selection activities on a characteristic will provide meaningful genetic progress. The heritability value for the selected character determines the effectiveness characteristics (Pratap et. al., 2012). The influence of additive genes causes selection activities to be more effective (Sathya and Jebaraj, 2013). Jambormias et al., (2004) state that a high heritability value of a characteristic indicates that the phenotypic variability in that generation is caused by genetic variability. Good characteristics to be used as selection criteria are those who have high heritability values (Begum et al., 2013). According to Fehr (1987), selection on the characteristics with high estimated values of heritability can be performed on the early generation, while selection on the characteristics with low heritability is carried out in the late generation. According to Basavaraja et al., (2013), the knowledge of heritability determines the genetic advance under selection. Heritability and genetic advance are two selection parameters assessed during this study.
Genetic variability is expressed by the genotypic variance value and genotypic coefficients of variation. If the genetic coefficient of variation is higher than the genotypic deviation standard, the genetic variability is classified broad. Meanwhile, if the genetic coefficient of variation is equal to or smaller than the genotypic deviation standard, the genetic variability is classified narrow. Heritability in the broadest sense involves total genetic diversity (both addictive and dominant), and if it involves only the genetic variety of addictive, it is narrowly categorized.

These results indicate that the environment has little influence on the expression of a character because morpho-agronomic characteristics are generally influenced by additive genes (Kahrizi et al., 2010). Broad genetic variability in these characteristics indicates that these characteristics can be improved because they are more flexible to be selected (Yunianti, 2010). The genetic and phenotypic variance values are used to estimate the value of broad-sense heritability. According to Hallauer and Miranda (1981), the effectiveness of selection is highly dependent on the estimated value of heritability and the presence of genetic diversity of the selected material. The high estimated values of heritability and genotypic coefficient of variation of the observed characteristics are possible for effective selection (Haq et al., 2008). In addition, quantitative characteristic selection can be carried out based on the values of the genetic parameters without neglecting the middle value of the population concerned.

\section{Coefficients of Correlation Between Agronomic Char-} acteristics of Potato

Estimation of correlation analysis aims to study the relationships between characteristics and select the main characteristics that have always been the goals of improvement in each plant breeding pro- 
Table 3. Correlation between several agronomic characteristics of 30 potato lines resulted from crossing

\begin{tabular}{|c|c|c|c|c|c|c|c|c|}
\hline Characteristics & $\begin{array}{l}\text { Plant } \\
\text { height } \\
(\mathrm{cm})\end{array}$ & $\begin{array}{l}\text { Stem } \\
\text { diameter } \\
(\mathrm{cm})\end{array}$ & $\begin{array}{l}\text { Number } \\
\text { of leaves }\end{array}$ & $\begin{array}{l}\text { Diameter } \\
\text { of tuber } \\
(\mathrm{cm})\end{array}$ & $\begin{array}{l}\text { Number } \\
\text { of tubers }\end{array}$ & $\begin{array}{l}\text { Length of } \\
\text { tuber } \\
(\mathrm{cm})\end{array}$ & $\begin{array}{l}\text { Weight / } \\
\text { tuber } \\
\text { (g) }\end{array}$ & $\begin{array}{l}\text { Starch } \\
\text { content } \\
(\%)\end{array}$ \\
\hline Stem diameter $(\mathrm{cm})$ & $0.788^{* *}$ & & & & & & & \\
\hline Number of leaves & $0.786^{* *}$ & $0.750^{* *}$ & & & & & & \\
\hline Diameter of tuber $(\mathrm{cm})$ & $0.571^{* *}$ & $0.589^{*}$ & $0.359^{*}$ & & & & & \\
\hline Number of tubers & $0.407^{\star}$ & $0.382^{*}$ & $0.501^{* *}$ & $0.359^{\text {ns }}$ & & & & \\
\hline Length of tubers $(\mathrm{cm})$ & $0.383^{\text {ns }}$ & $0.230^{\mathrm{ns}}$ & $0.314^{*}$ & $0.501^{*}$ & $0.337^{*}$ & & & \\
\hline Weight /tuber (g) & $-0.117^{* *}$ & $-0.126^{* *}$ & $-0.316^{*}$ & $0.314^{* *}$ & $-0.221^{\text {ns }}$ & $-0.238^{*}$ & & \\
\hline Starch content (\%) & $0.531^{\mathrm{ns}}$ & $0.393^{\mathrm{ns}}$ & $0.458^{*}$ & $-0.316^{\mathrm{ns}}$ & $0.399 \mathrm{~ns}$ & $0.396^{\mathrm{ns}}$ & $-0.086^{\mathrm{ns}}$ & \\
\hline Glucose (\%) & $0.605^{* *}$ & $0.508^{* *}$ & $0.465^{*}$ & $0.458^{*}$ & $0.032^{*}$ & $0.305^{*}$ & $-0.177^{\mathrm{ns}}$ & $0.386^{*}$ \\
\hline
\end{tabular}

Remarks: ns: Not significant, *: Significant at alpha level of $5 \%$, **: Significant at alpha level of $1 \%$

Table 4. Direct and indirect effects of agronomic characteristics on the weight per tuber

\begin{tabular}{|c|c|c|c|c|c|c|c|c|c|c|}
\hline \multirow[b]{2}{*}{ Variables } & \multirow[b]{2}{*}{$\begin{array}{l}\text { Estimation } \\
\text { of Direct }\end{array}$} & \multicolumn{8}{|c|}{ Estimation of Indirect } & \multirow[b]{2}{*}{ Total } \\
\hline & & $\begin{array}{l}\text { Plant } \\
\text { height } \\
(\mathrm{cm})\end{array}$ & $\begin{array}{l}\text { Stem } \\
\text { diameter } \\
(\mathrm{cm})\end{array}$ & $\begin{array}{l}\text { Number } \\
\text { of } \\
\text { leaves }\end{array}$ & $\begin{array}{l}\text { Diameter } \\
\text { of tuber } \\
(\mathrm{cm})\end{array}$ & $\begin{array}{l}\text { Number } \\
\text { of } \\
\text { tubers }\end{array}$ & $\begin{array}{l}\text { Length } \\
\text { of } \\
\text { tubers } \\
(\mathrm{cm})\end{array}$ & $\begin{array}{l}\text { Starch } \\
\text { content } \\
(\%)\end{array}$ & $\begin{array}{c}\text { Glucose } \\
(\%)\end{array}$ & \\
\hline Stem diameter $(\mathrm{cm})$ & 0.621 & - & $-0,100$ & -0.102 & 0.375 & -0.281 & 0.025 & 0.143 & -0.078 & 0.605 \\
\hline Number of leaves & -0.127 & 0.488 & - & -0.105 & 0.352 & -0.169 & 0.027 & 0.106 & -0.065 & 0.508 \\
\hline Diameter of tuber $(\mathrm{cm})$ & -0.178 & 0.355 & -0.075 & - & 0.462 & -0.230 & 0.068 & 0.124 & -0.060 & 0.465 \\
\hline Number of tubers & 0.921 & 0.253 & -0.048 & -0.089 & - & -0.367 & -0.067 & -0.085 & -0.059 & 0.458 \\
\hline Length of tubers $(\mathrm{cm})$ & -0.733 & 0.238 & -0.029 & -0.056 & 0.462 & - & 0.047 & 0.108 & -0.004 & 0.032 \\
\hline Weight /tuber (g) & -0.214 & -0.073 & 0.016 & 0.056 & 0.289 & 0.162 & - & 0.107 & -0.039 & 0.305 \\
\hline Starch content (\%) & 0.270 & 0.330 & -0.050 & -0.082 & -0.291 & -0.293 & -0.085 & - & 0.023 & -0.177 \\
\hline Glucose (\%) & -0.128 & 0.376 & -0.064 & -0.083 & 0.422 & -0.023 & -0.065 & -0.048 & - & 0.386 \\
\hline
\end{tabular}

gram. Estimation of correlation analysis between the characteristics tested is shown in Table 3.

The results showed that almost all the characteristics studied were found to have positive and significant correlations. This indicates that a selection of one character will affect the other characteristics. In addition, positive and negative correlations indicate that changes in a characteristic will be followed by the changes in other characteristics regularly in the same and opposite direction, respectively. Characteristics that have a positive and significant correlation coefficient can be used as selection criteria because an increase in a characteristic will increase the other characteristics.

Characteristics that have a negative coefficient of correlation show the opposite response so that they are not used as selection criteria. Characteristics that have a positive correlation coefficient can be used as selection criteria by selecting individuals who have the highest characteristics values (Boer,
2011). According to Wirnas et al., (2006), characteristics negatively correlated with yield are not recommended as selection criteria. Selection will be more effective if it is also carried out indirectly through positively correlated characteristics with yield.

Estimation of Direct, Indirect and Total Effect of Agronomic Characteristics on the Weight per-Tuber

The direct and indirect effects of different characteristics were determined using path coefficient analysis in the correlation against yield, to get the interrelationships between different characteristics (Singh et al., 2004). Yield is a very complex character influenced by various characteristics so that selection based on the yield directly may not be very efficient (Mahajan et al., 2011). Therefore, knowledge of the relationship between yield and characteristics contributes is beneficial in evaluating and developing high-yield potatoes. 


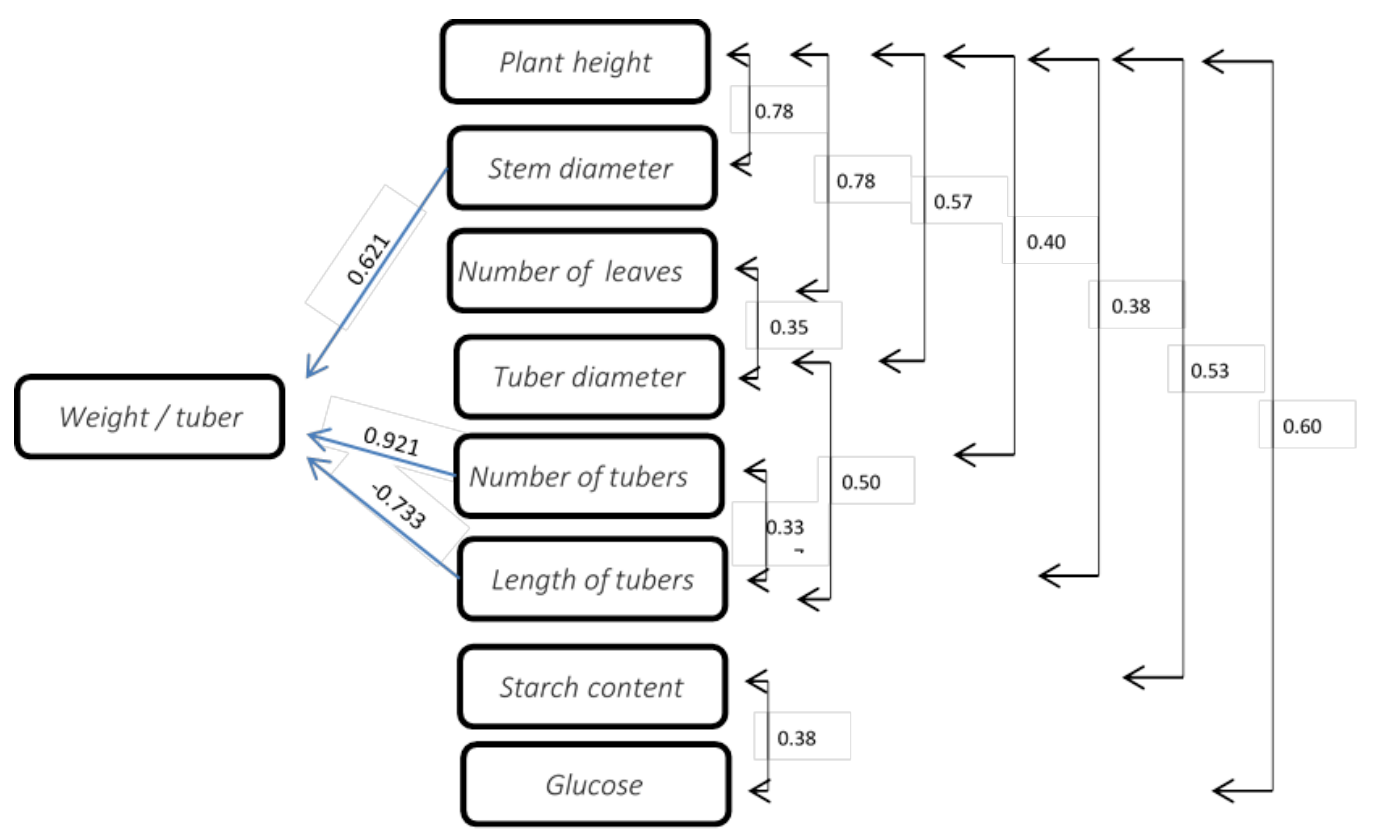

Figure 1. Path Analysis of Agronomic Characteristics on the Weight per-Tuber

The estimates of the direct, indirect, and total effects of yield components on the weight per tuber are presented in Table 4. A path diagram showing the relationships between yield and its components is presented in Figure1. Table 4 showed that tubers have the largest direct effect on weight/tuber, followed by the stem diameter. A direct effect of the number of tubers on the weight per tuber also involves the indirect effect of several variables. Stem diameter has a positive and significant correlation with the number of leaves. The number of leaves is positively correlated with the number of tubers. Thus, the number of tubers affects the weight per tuber. This result is due to the relationship between source and sink. The leaf as a source organ is positively correlated with the number of tuber and weight per tuber as sink organs.

In addition to genetic characteristics, a phenotype also plays a role due to environmental conditions. According to Su-May et al., (2015), at the germination or seedling development stage, to support initial growth of seedlings, minerals produced from the hydrolysis of stored nutrients in the endosperm (source) are transported to the embryo (sink). The result of photosynthesis (Sucrose) in mature leaves (source) is translocated through the phloem, to developing leaves (sink), at the vegetative stage. Sucrose is produced by photosynthesis and is translocated to developing tuber (sink), during the tuber-filling stage. Various nutrients, particularly $\mathrm{N}$, and minerals in leaves (source) are also remobilized to developing tuber. The characteristics that can be used to determine the selection criteria have several considerations. These are genetically correlated strongly with the target characteristic, have a high heritability value, and be easily visually observed (Roy, 2000).

\section{Selection of Potato Lines}

The selection of the lines tested was based on heritability values, genetic coefficients of variation, genetic correlation coefficients, and the value of direct and indirect effects of agronomic characteristics on the yield. Selection of potato lines can be carried out using plant height, stem diameter, number of leaves, the diameter of tuber, number 
Table 5. Selection of potato lines

\begin{tabular}{|c|c|c|c|}
\hline Lines & $\begin{array}{c}\text { Plant height }[\mathrm{cm}] \\
24.35-61-60\end{array}$ & $\begin{array}{c}\text { Diameter of tuber }[\mathrm{cm}] \\
2.16-2.96\end{array}$ & $\begin{array}{c}\text { Number of Tuber } \\
7.18-15.3\end{array}$ \\
\hline $\begin{array}{l}\text { UPRSD1-AP4-1 } \\
\text { UPRSD1-AP4-2 } \\
\text { UPRSD1-AP4-3 } \\
\text { UPRSD 1-AP4-4 } \\
\text { UPRSD1-AP4-5 } \\
\text { UPRSD1-AP4-6 } \\
\text { UPRSD1-AP4-7 } \\
\text { UPRSD1-AP4-8 } \\
\text { UPRSD1-AP4-9 } \\
\text { UPRSD1-AP4-10 } \\
\text { UPRSD1-AP4-11 } \\
\text { UPRSD1-AP4-12 } \\
\text { UPRSD1-AP4-14 } \\
\text { UPRSD1-AP4-15 } \\
\text { UPRSD1-AP4-16 } \\
\text { UPRSD1-AP4-17 } \\
\text { UPRSD1-AP4-18 } \\
\text { UPRSD1-AP4-19 } \\
\text { UPRSD1-AP4-20 } \\
\text { UPRSD1-AP4-21 } \\
\text { UPRSD1-AP4-22 } \\
\text { UPRSD1-AP4-23 } \\
\text { UPRSD1-AP4-24 } \\
\text { UPRSD1-AP4-25 } \\
\text { UPRSD1-AP4-26 } \\
\text { UPRSD1-AP4-27 } \\
\text { UPRSD1-AP4-28 } \\
\text { UPRSD1-AP4-29 } \\
\text { UPRSD1-AP4-30 } \\
\text { UPRSD1-AP4-36 }\end{array}$ & $\begin{array}{c}43.493 \\
60.770 \\
31.163 \\
49.378 \\
47.905 \\
47.279 \\
59.643 \\
48.274 \\
49.496 \\
31.823 \\
58.748 \\
41.759 \\
37.762 \\
56.518 \\
26.585 \\
34.522 \\
45.685 \\
19.651 \\
38.441 \\
35.102 \\
16.470 \\
9.064 \\
24.318 \\
39.695 \\
27.496 \\
26.363 \\
33.386 \\
46.519 \\
16.064 \\
38.587 \\
\end{array}$ & $\begin{array}{l}2.504 \\
2.515 \\
2.267 \\
2.532 \\
2.895 \\
2.729 \\
3.170 \\
2.592 \\
2.732 \\
2.197 \\
3.038 \\
2.259 \\
2.640 \\
2.921 \\
3.105 \\
2.371 \\
2.768 \\
1.896 \\
3.150 \\
1.771 \\
2.564 \\
1.710 \\
2.457 \\
2.117 \\
2.186 \\
2.514 \\
3.176 \\
2.530 \\
2.153 \\
2.629 \\
\end{array}$ & $\begin{array}{c}18.371 \\
12.068 \\
11.698 \\
9.558 \\
5.924 \\
11.150 \\
11.068 \\
13.180 \\
13.031 \\
10.101 \\
17.104 \\
17.816 \\
12.669 \\
11.623 \\
7.882 \\
9.809 \\
15.409 \\
5.077 \\
14.928 \\
14.068 \\
4.191 \\
14.327 \\
5.077 \\
12.993 \\
12.327 \\
9.990 \\
7.549 \\
11.409 \\
7.077 \\
19.327 \\
\end{array}$ \\
\hline
\end{tabular}

of tubers, weight per tuber, starch content, and glucose. The selection of the lines tested was carried out by the criteria of plant height (24.35 - 61.60 $\mathrm{cm})$, the diameter of tuber $(2.16-2.96 \mathrm{~cm})$, and the number of tubers $(7.18-15.3)$. There were 15 selected lines that met the criteria (Table 5).

Selection is selecting the best individual plants based on the desired characteristic (Phillips and Wolfe, 2005). Selection will be effective if the right selection criteria is used. The selection of selection criteria is based on the characteristic's genetic values, such as heritability or coefficient of correlation values (Nasution, 2010). Selection can be done using one or several characteristics (Babu, 2012; Rachman, 2010). Based on research and analysis that has been done, it can be concluded that plant height, the diameter of tuber, and the number of tubers can be used as selection criteria.

\section{CONCLUSION}

1. The high heritability of 30 potatoes lines was found in the characteristics of plant height, number of leaves, the diameter of tuber, number of tubers, weight per tuber, starch content, and glucose.

2. The genetic variability of the 30 potatoes lines on the characteristic of plant height, number of leaves, number of tubers, starch content, glucose, and the weight per tuber is slightly low, while on the other characteristics is low. The lines produced are pure strains so that the individuals in the same line have almost uniform phenotypes.

3. The characteristics of plant height, stem diameter, number of leaves, the diameter of tuber, number of tubers, and glucose correlate with weight per tuber.

4. The agronomic characteristics in this study that can be used as selection criteria are plant height, the diameter of tuber, and the number of tubers. 


\section{REFERENCES}

Acquaah G. (2007). Principles of Plant Genetics and Breeding. Oxford (UK): Blackwell Publishing Ltd.

Akhmadi, G., Purwoko, B.S., Dewi, I.S., \& Wirnas, D. (2017). Pemilihan karakter agronomi untuk seleksi pada galur-galur padi dihaploid hasil kultur antera. J. Agron. Indonesia, 45(1), 1-8. DOl: https:// doi.org/10.24831/jai.v45i1.13681

Akmal, Gunarsih, C., \& Sanaullah, M.Y. (2014). Adaptation and stability of aromatic rice lines in North Sumatera (in Indonesian). Food Crop Res. J., 33(1), 9-16. DOl: https://doi.org/10.21082/ ipptp.v33n1.2014.p9-16

Babu, R.V., Shreya, K., Dangi, K.S., Usharani, G., \& Shankar, A.S. (2012). Correlation and path analysis studies in popular rice hybrids of India. Int. J. of Sci. and Res. Publ., 2(3), 1-5. DOI: https://doi=10.1.1.307.6810

Basavaraja, T., Asif, M., Mallikarjun, S.K., \& Gangaprasad S. (2013). Variability, heritability and genetic advance for yield and yield attributing characters in different local rice (Oryza sativa L.) cultivars. Asian J. Of Bio. Sci., 8(1), 60-62.

Begum, S., Noor, M., Rahman, H.,U., Hassan, G., Durrishahwar, Ullah, U., Alia \& Ali, F. (2013). Heritability Estimates and Correlations among Flowering and Yield Related Traits in Mungbean Genotypes. British Journal of Applied Science \& Technology 3(3), 472-481. DOl: https://doi.org/10.9734/BJAST/2014/2588

Boer, D. (2011). Analisis variabilitas genetik dan koefisien lintas berbagai karakter agronomi dan fisiologi terhadap hasil biji dari keragaman genetik 54 asesi jagung asal Indonesia timur. Agroteksos. 135-43.

Bowman, D., T. (2001). Common use of the CV: a statistical aberration in crop peformance trials. JCS. 5, 137-141.

Fehr, W., R. (1987). Principle of Cultivar Development. Macmillan. New York: London.

Govindaraj, M., Vetriventhan M., \& Srinivasan M. (2014). Importance of genetic diversity assessment in crop plants and its recent advances: an overview of its analytical perspectives. Genetics Research International 2015:1-14. DOI: https://doi.org/10.11 55/2015/431487Hallauer, A., \& Miranda, J. (1981). Quantitative Genetics in Maize Breeding. lowa State University Press. Ames, IA.

Hallauer, A., \& Miranda, J. (1981). Quantitative Genetics in Maize Breeding. lowa State University Press. Ames, IA.

Haq, W., U., Malik, M., F., Rashid, M., Munir, M., \& Akram, Z. (2008). Evaluation and estimation of heritability and genetic advancement for yield related attributes in wheat lines. Pak. J. Bot. 40(4), 1699-1702.

Hartati, R., S., Setiawan, A., Heliyanto, B., \& Sudarsono. (2012). Keragaman genetik, heritabilitas, dan korelasi karakter 10 genotipe terpilih jarak pagar (Jatropha curcas L.). J. Littri. 18, 74-80. DOl: https://doi.org/10.21082/jlittri.v18n2.2012.74-80

Herawati, R., Purwoko, B., S., \& Dewi, I., S. (2009). Genetic diversity and agronomic character of haploid double line of upland rice with new types of anther culture. J Agron Indonesia 37(2), 87-94.

Jambormias, E., Sutjahjo, S., H., Jusuf, M., \& Suharsono. (2004). Keragaan, Keragaman Genetik dan Heritabilitas Sebelas Sifat Kuantitatif Kedelai (Glycine max L. Merrill) pada Gen- erasi Seleksi F5. Jurnal Pertanian Kepulauan 3(2), 115-124.

Kahrizi, D., Maniee, M., Mohammadi, R., \& Cheghamirza, K. (2010). Estimation of genetic parameters related to morpho-agronomic traits of Durum Wheat (Triticum turgidum var. durum). Biharean Biologist 4(2), 93-97.

Khan, N., U., Hassan, G., Kumbhar, M., B., Parveen, A., Aiman, U., Ahmad, W., Shah, S., A., \& Ahmad, S. (2007). Gene action of seed traits and oil content in upland cotton (G. hirsutum). SABRAO J Breed Genet. 39, 17-30.

Kwon, S., H., \& Torrie, J., H. (1964). Heritability and inter-relationship of traits of two soybean populations. Crop Sci. 4(1), 196-198. DOI: https://doi.org/10.2135/cropsci1964.0011183X00040 $\underline{0020023 x}$

Lubis, K., Lubis, A., M., Siregar, L., A., M., Lisnawita, Safni, I., \& Tantawi, A., R. (2018). Root morphology of several potato varieties infected Meloidogyne spp. and addition of organic matters. International Conference on Agriculture, Environment, and Food Security IOP Publishing IOP Conf. Series: Earth and Environmental Science 122, 1-7. DOl: https://doi.org/10.1088/17551315/122/1/012025

Mahajan, R., C., Wadikar, P., B., Pole, S., P., \& Dhuppe, M., V. (2011). Variability, Correlation and Path Analysis Studies in Sorghum. Research Journal of Agricultural Sciences. 2(1), 101-103.

Mondal, M., A., A., Hossain, M., M., Rasul, M., G., \& Uddin, M., S. 2007. Genetic diversity in potato (Solanum tuberosum L). Bangladesh J. Bot. 36(2), 121-125. DOl: https://doi.org/10.3329/bjb. v36i2.1499

Nasiruddin, M., Haydar, F., M., A., \& Islam, A., K., M., R. (2017). Genetic diversity in potato (Solanum tuberosum $L$.) genotypes grown in Bangladesh. International Research Journal of Biological Sciences 6(11), 1-8.

Nasution, M., A. (2010). Genetic correlation and path analysis between morphological and fruit componen characters of pineapple (Ananas comosus L. Merr.). Crop. Agro. 3, 5-14.

Ozturk, G., \& Yildirim, Z. (2014). Heritability estimates of some quantitative traits in potatoes. Turkish Journal of Field Crops. 19(2), 262-267. DOl: https://doi.org/10.17557/tjfc.66538

Pangemanan, V., Runtunuwu, D., S., \& Pongoh, J. (2013). Genetic Variability And Morphologic Heritability Characters of Some Genotypes Of Potato. Eugenia 19(2). DOI: https://doi. org/10.35791/eug.19.2.2013.7164

Phillips, S., L., \& Wolfe, M., S. (2005). Evolutionary plant breeding for low input systems. Journal of Agricultural Science 143, 245-254. DOl: https://doi.org/10.1017/S0021859605005009

Pinaria, A. Baihaki, A., Serimihardja, R., \& Darajat AA. (1995). Variabilitas genetik dan heritabilitas karakter-karakter biomasa 53 genotipe kedelai. Zuriat 6(2): 88-92.

Pratap, N., Singh, PK., Shekhar, R., Soni, SK., \& Mall, AK. (2012). Genetic variability, character association and diversity analyses for economic traits in rice (Oryza sativa L.). SAARC J. Agri., 10(2): 83-94. DOl: https://doi.org/10.3329/sja.v10i2.18326

Rachman, M. (2010). Korelasi dan analisis koefisien lintas karakter tandan bunga terhadap buah jadi kelapa genjah salak. Palma. 38, 60-66. DOI: https://doi.org/10.3329/bjpbg.v29i1.33704

Rahman, M., H., Islam, M., S., \& Sonom, M. (2016). Genetic Diversity of Potato (Solanum tuberosum L.). Bangladesh J. Pl. Breed. Genet. 29(1), 39-43. 
Roy, D. (2000). Plant Breeding: Analysis and Exploitation of Variation. Narosa Publishing House. New Delhi.

Sathya, R., \& Jebaraj, S. (2013). Heritability and genetic advance estimates from three line rice hybrids under aerobic condition. Int. J. Agric. Sci. and Res. 3(3), 69-74.

Singh, R., K., \& Chaudhary, B., D. (1979). Biometrical methods in quantitative genetic analysis. Kalyani Publisher, Ludhiana. New Delhi.

Singh, V., Desphande, M., B., Choudri, S., V., \& Nimbkar, N. (2004). Correlation and path coefficient analysis in safflower (Carthamus tinctorius L.). Sesame Safflower. Newslett. 19, 77-81.

Stansfild, W., D. (1991). Schaum's outline of theory and problems of genetics, 3rd ed., The McGraw-Hill Companies. New York.

Statistik Konsumsi Pangan. (2018). Data Statistik Konsumsi Pangan Tahun 2018. http://epublikasi.setjen.pertanian.go.id/ epublikasi/StatistikPertanian/2018/Konsumsi/Statistik Konsumsi Pangan Tahun 2018/files/assets/basic-html/page56. html. Diakses tanggal 1 Februari 2019.

Steel, R., G., D., Torrie, J., H., \& Dicky, D., A. (1997). Principles and procedures of Statistics. A Biometrical Approach (3rd ed., pp. 400-428). McGraw Hill Book Co. Inc. New York.

Su-May, Y., Shuen-Fang, L., \& Tuan-Hua, D., H. (2015). Source-Sink Communication: Regulated by Hormone, Nutrient, and Stress Cross-Signaling. Trends in Plant Science. 20(12), 844-857. DOI: https://doi.org/10.1016/j.tplants.2015.10.009

Wirnas, D., \& Widodo, I., Trikoesoemaningtyas, \& Sopandie, D. (2006). Pemilihan karakter agronomi untuk menyusun indeks seleksi pada 11 populasi kedelai generasi F6. Bul. Agron. 34, 19-24. DOI: https://doi.org/10.24831/jai.v34i1.1270

Yunianti, R., Sastrasumarjo, S., Sujiprihati, S., Surahman, M., \& Hidayat, S. (2010). Kriteria seleksi untuk perakitan varietas cabai tahan Phytophtora capsici Leonian. J. Agron. Indonesia 38(2), 122-129.

Zen, S. (2012). Parameter genetik padi sawah dataran tinggi. Pertanian Terapan. 12(3), 196-201. DOl: https://doi.org/10.25181/ ippt.v12i3.217 